\title{
JOHN WARD, F.G.S.
}

Bory Acgust 11, 1837. Died November 30, 1906.

Tнв death of $\mathrm{Mr}$. John Ward, of Longton. Staffordshire, removes. from the Midlands one of its best known and most active geologists and palæontologists. Mr. Ward leroted the leisure of his busy life to a detailed study of the North Staffordshire Coalfield and its fossils. He was a pioncer in the collection of fossils to illustrate accurately their zonal distribution; and he met with great success not only in unrarelling the stratigraphy of the Coal-measures, but also in the discovery of a large number of well-preserred fossil fishes, which werenew to science and contributed to a great advance in our knowledge. of Palæozoic Ichthyology.

Mr. Ward was born at Fenton, North Staffordshire, in i 837, and was educated at Iry House School, Hanley. Early in life he entered on a business career, which occupied him until the end, and only left him scanty leisure for the pursuit of studies. When quite young, he came under the influence of Dr. Robert Garner (author of the wellknown "Natural History of the County of Stafford," 1844), who. encouraged him in the geological researches which became the main recreation of his life. In 1865 he attended the meeting in Stoke at which the North Staffordshire Field Club was established, and continued for forty years to be one of its most active members.

Mr. Ward's geological researches had as their chief aim the identification and correlation of the more important coal-seams of North Staffordshire by their fossils; and one of his earliest discoveries was that of marine bands intercalated at definite horizons in the Coal-measure series. His observations were first summarised in 1890 in his exhaustive volume on "The Geological Features of the North Staffordshire Coalfields," published by the North Staffordshire Institute of Mining Engineers. His final conclusions formed the subject of some valuable chapters on the "Palæontology of the Pottery Coalfield," which he contributed to the Geological Survey Dlemoir in 1905 .

Mr. Ward was also an accomplished palæontologist and made many important observations on the fossils in his collection, but he rarely attempted palæontological descriptions. His fossil fishes were studied and deseribed by Egerton, Huxley, John Young, James W. Davis, Dr. Traquair, and the present writer, some of the most important researches of Dr. Traquarr having been based almost entirely on the specimens obtained from the Coal-measures of Longton and Fenton. IIr. Ward's name, however, is permanently associated with his discoreries in numerous instances, such as those of Acanthodes Wardi, Listracanthus Wardi, Mftsolepis Wardi, Rhadinichthys Wardi, and others. 'The Lower Carboniferous Platysomid genus I'ardichthys is also named after him.

When, by the closing of certain coal-pits, opportunities for collecting fossil fishes became fewer, Mr. Ward decided to offer his collection to the British Museum, and the principal part of it was purchased by the Trustees in 1894. After that year he devoted attention more especially to the Mollusca and Plants, which were described respectively by Dr. Wheelton Hind and Mr. R. Kidston; though he still never 
neglected any opportunity of obtaining fish-remains, and among these his latest most important discovery was that of a new Listraeanthu. in direct association with the so-called Petrodus. ${ }^{\text {a }}$

Mr. Ward was elected a Fellow of the Geological Society in 1874 , and received a moiety of the Lyell Fund from that Society in 1899 in recognition of the value of his long-continued researches. In 1895 the North Staffordshire Field Club also honoured him by the award of the Garner Memorial Medal. Only a small proportion of Mr. Ward's work, however, is embodied in his published writings. He was an unassuming and unselfish, enthusiastic student, whose knowledge was at the disposal of everyone who went to consult him. The little library in the room above his shop, and the dark basement in which he kept his collection for so many years, were the familiar haunts of all who were interested in the English Coal-measures. His robust physique enabled him to participate in active field-work almost until the end of his life, and he was always ready to accompany enquirers to any part of the district he knew so well. His genial presence will be missed by a large circle of friends who mourn his loss.

\section{List of Paperes bY John Ward, F.G.S.}

\section{A. S. W.}

1861. "Fenton Park: its Icbthyolite Remains": Potteries Mechanics' Mag., vol. ii, p. 137 .

1865. Letters on "Marine Fossils in Coal-measures": Geol. Mag., Dec. I, Vol. II, pp. 234, 286.

"The Distribution of the Oroanic Remains of the North Staffordshire Coalfield" : Trans. Dudley and Midland Geol. Soc., vol. ii, p. 21.

1870. "Notes on the Fossil Trees in Messrs. Hampton's Marl Pit at Joiners' Square, Hanley": Rep. N. Staffs. Nat. Field Club.

"The Fossil Fishes of the Sorth Staffordshire Coalfield": Trans. Midland Sci. Assoc., pt. ii.

1875. "Notes on the Fossil Trees in a Marl Pit at Hanley": Addresses and Papers X. Staffs. Yat. Field Club, pp. 80-86.

"On the Organic Remains of the Coal-measures of North Staffordshire, their Range and Distribution, with a Catalogue of the Fossils and their Mode of Occurrence" : loc. cit., pp. 18t-251, with plate.

1878. "Notes on some Fossil Trees in a Marl Pit at Joiners' Square, near Hanley " : Rep. N. Staffs. Nat. Field Club.

1880. The same, with further notes: loc. cit.

1889. "The Lower Coal-measures of the Cheadle Coalfield, with Special Reference to the Recent Boring for Ironstone at the Park Hall Colliery, Cheadle" : loc. cit., pp. 88-91.

1890. "The Geological Features of the North Staffordshire Coalfields; their Organic Remains, their Range and Distribution, with a Catalogue of the Fossils of the Carboniferous System of North Staffordshire ": 'Trans. $N$. Staffs. Inst. Mining Engineers, vol. x, pp. 1-189, pls. i-ix.

1893. "The Progress of Geological and Palacontological Research in $N$ orth Staffordshire, with Summary of Literature relating to the Geologr, Mineralogy, and Palæontology of North Staffordshire" : Trans. N. Staffs. Nat. Field Club, vol. xxvii, pp. 67-107 (continued in vol. xxix, 1895, pp. 105, 106).

1895. "On the Occurrence of Marine Fossils in the Coal-measures of North Staffordshire" : loc, cit., rol. xxix, pp. 129-138.

1900. "On a newly-discovered Marine Bed in the Coal-measures of North Staffordshire" : loc. cit., vol. xxxiv, pp. 87-92.

1905. "Palcontology of the Pottery Coalfield": in "The Geology of the North Staffordshire Coalfields," Mem. Geol. Surv.

1 A. S. Woodward, "On the Carboniferous Lchthyodorulite Listracanthus": Geol. MAG., Dec. IY, Vol. X (1904), pp. 486-488, with figs. 
1906. [With Jorx T. Stonps.] "A newly-discovered Fish Bed in the Cheadle Coalfield; with Notes on the Distribution of Fossil Fishes in that District"': 'Trans. X. Staffs. Nat. Field Club, vol. xl, pp. 87-101, pl. i.

"Palcontology of the Cheadle Coalfield": loc. cit., rol. xl, pp. 102-137, pl. ii.

\section{CAROLINE BIRLEY.}

Bors Tovember 16, 1851.

Difd Febrtary 15, 1907.

Br the death of Miss Caroline Birley a most ardent and enthusiastic student has been lost to the science of Geology, one who from her childhood to the end of her life never wavered in devotion to this her cherished pursuit, nor thought any fatigue or personal sacrifice too great in order to visit places of geological interest and obtain specimens for her beloved Museum.

Caroline Birley was the youngest daughter of $\mathrm{Mr}$. Thomas Hornbr Birley, who resided at Hart Hill, near Manchester. When a child her holidays were constantly spent in the Isle of Man, where her grandfather, Lieut.-Col. Leatham, resided after his retirement from the Army. Her earliest delight was to select specimens of stones showing any peculiarity, and when about 9 years of age she commenced to form a collection, to which she continued most assiduously to add when travelling in England or on the Continent. When the Geological Magazine commenced its existence in 1864 this young enthusiast of 13 years of age became a regular monthly subscriber, devoting her porket-money to this periodical! After a year of self-denial her grandmother, discovering this sacrifice to the cause of geological science, made her granddaughter a special allowance to purchase this coveted journal.

In the year 1888 Miss Caroline Jirley's collection had already outgrown the space in her house at Seedley Terrace, Manchester, and she erected an iron building in the garden as a museum. In 1888 Miss C. Birley visited Faxe, Denmark, and again in the Summer of 1891, when she made a large collection of Upper Cretaceous fossils. The Crustacea thus obtained were described by Dr. H. Woodward in the Geological Magazine for November, 1901 (pp. 486-501, Pl. XII). Two new species of the genus Dromiopsis (D. Birleyce and D. Coplanda) obtained in that expedition were figured and described by him, and dedicated to Miss C. Birley and her friend and fellow-traveller, Miss L. Copland.

In June, 1889, Miss Birley and her friend Miss Copland visited the Freroes, bringing back from the islands of Stromoe, Naalsoe, and Osteroe six hundredweights of rocks containing zeolites. In 1890 she paid a second risit to the Færoes. In that year Miss Birley became a member of the Geologists' Association, to the excursions and meetings of which Society she was always afterwards a very constant attendant. She also, later on, in 1894, joined the Malacological Society of London, and frequently attended its meetings. In Norember, 1891, Miss Birley and Miss Copland went to Malta and did a considerable amount of collecting from the 'Tertiary strata of that island. In 1892 the laclies visited Algeria, but did not succeed in making a very large collection there. 